- immences with mis-stating facts, and then proceeds to inferences, which the alleged facts, even if true, would not warrant.

His fitst : mis statement is the following, viz.s6. The dimner, wa believe, was but thinly attended, the company being nearly two-thirds less than it was last year at Southampton." This statement happens to be untrue; and as the editor was not himself present at the dinner, we charge him only with asserting, on insufficient grounds, what he did not know to be true. Relatively to the number of members present at the meeting, the dinner was not thinly attended, the guests bearing as full a proportion to the whole number of assembled members as on any former occasion. The dinner company was not two-thirds less than ivwas last year at Southampton. I, Sir, who did attend the dinner, counted the guests, and found them to amount to seventy. Will the editor of the Medical Press allege, that the attendants at the Southampton dinner amounted to 210 ?

But, even if there were a thin attendance at dinner, there were, surely, other causes to which to refer this, without imputing it solely to repulsion, caused by the alleged misconduct of the secretary. The meeting had occupied above two days; many members had attended from extreme distances, and were naturally anxious to return to thein homes; they were under the necessity, too, of availing themselves of the most convenient railtrains for carrying them back to their respective districts. Even the cost of the usual dinner is well known to have effect in thinning the dinner attendance. Taking into account these several causes of absence from the dinner, I hesitate not to pronounce, that relatively to the whole number of members assembled at York, the dinner was not thinly, but fully attended.

Assuming a thin attendance, the writer of the objectionable paragraph immediately proceeds to assign the conduct of the secretary as the cause of this; and, referring to a casual discussion which took place at the meeting, he expressly charges Dr. Hastings with " an intemperate and vulgar attack on Dr. Laycock," and with " attempts to stifle discussion by brawling and bombast."

They who heard the discussion alluded to, will find it difficult to recognise it in this splenetic representation; while all the absent members who have any knowledge of Dr. Hastings, will at once repudiate the gross accusation as wholly unworthy of belief.

So far from Dr. Hastings making an intemperate and vulgar attack on Dr. Laycock, he was himself the party assailed; and only in defence of the secretaries, the council, and the constitution of the association, did he reply. Dr. Laycock more than insinuated, that the government of the association was not representative of the general members; that the council was arbitrarily chosen; that the secretaries exercised despotic power. Against these groundless and unexpected imputations, Dr. Hastings did earnestly vindicate the parties arraigned. Were the imputations true, it would hare been the bounden duty of the detector of such abuses, either to have impeached the secretaries as guilty of violating the fundamental laws ; or, if he found the laws defective, to have given notice of an express motion for correcting them.

But Dr. Laycock's remarks being as untrue in fact, as they were unappropriate to the occasion on which they were uttered, Dr. Hastings; precisely as his duty required, rebutted them by a direct refutation, which none but the Editor of the Medical Press would venture to call intemperate and vulgar, or characterise as brawling and bombast.

For Dr. Hastings' reputation, Sir, I have no fears, for it rests on too stable a foundation to be thus damaged. But I would caution the Editor of the Medical Press, as he values his journal, to beware of discrediting it by such unseemly personality as that which has called forth the present strictures.

$$
\begin{aligned}
& \text { Your obedient servant, } \\
& \text { August 12, 1841. }
\end{aligned}
$$

\section{RESULTS OF FORTY-TWO OPERATIONS} FOR THE CURE OF STAMMERING.

\section{By M. BONNET.}

THE author gives a short account of the results obtained by him in forty-two operations for the cure of stammering, by the subcutaneous method. In two patients no actual stammering existed, but the pronunciation of words was indistinct; no benefit ensued. In four cases he was also unsuccessful, where the impediment depended on some anomaly during respiration; the patients did repeat the same syllables over and over again, but enunciation was suddenly interrupted at the beginning or in the middle of a word. Of the remaining thirty-six patients, labouring under true stammer, six were above 32 years old. In the latter, the results were completely negative, and M. Bonnet thinks that the operation should never be performed on individuals who have passed the age of 32. Thirty patients were below this lastmentioned age; of these, ten were completely cured; eleven very greatly improved; two moderately so; and seven obtained no benefit. As under the head " greatly improved" are included cases where the impediment of speech was all but removed, it follows that the operation is attended with excellent effects in about two-thirds of the cases; but will these effects continue? This is an important question, which time alone can determine; of the ten patients completely cured, one relapsed to his former condition ten or twelve days after the operation; in another case, the stammer gradully returned about the fifth week; the other cases continue well at the present time (May 18th.) Amongst the eleven patients greatly relieved, two had relapses, but the remainder, on the other hand, were improving every day.

From these results it would appear, that we may expect some benefit from the operation for stammering, provided it be applied to the proper cases; but what these are, the present state of our knowledge does not permit us to say with any certainty.-Bul. de Therap. July, 1841.

\section{SUICIDES IN FRANCE.}

The number of suicides in France during the year 1839, amounted to 2,717; of these, 698 females, and 486 males, occurred in Paris. It is a melancholy fact, that self-destruction is daily on 